\title{
Survival chances of ground nests in three different habitats in Krka National Park (Croatia)
}

\author{
JENŐ J. PURGER ${ }^{1,2}$ \\ JASMINA MUŽINIĆ ${ }^{3}$ \\ ${ }^{1}$ Department of Ecology, Institute of Biology, \\ Faculty of Sciences, University of Pécs Ifjúság útja 6, \\ H-7624 Pécs, Hungary \\ ${ }^{2}$ BioRes Unlimited Partnership \\ Barackvirág u. 27, H-7624 Pécs, Hungary \\ ${ }^{3}$ Institute for Ornithology CASA \\ Gundulićeva 24, HR-10000 Zagreb, Croatia
}

Correspondence:

Jenő J. Purger

E-mail:purger@gamma.ttk.pte.hu

Key words: artificial nest, birds, Mediterranean region, predation, wetland.
Received November 28, 2015.

Revised October 12, 2016.

Accepted November 17, 2016.

\begin{abstract}
Background and Purpose: Diverse Mediterranean wetlands sustain a high diversity of breeding birds. Breeding success of birds nesting on protected wetlands along river Krka is also influenced by predators. The aim of our study was to explore effects of predator pressures on ground nests of strictly protected birds using artificial nests located along environmental gradient.
\end{abstract}

Materials and Methods: In May 2004 in locality Culisićke bare, by placing out three batches of 25 artificially constructed ground nests in three different habitats: reed bed, marsh and meadow. The nests contained three chicken (real) eggs for the evaluation of nest predation rates, and plasticine (artificial) eggs for predator identification from tooth and bill imprints.

Results and Conclusions: The number of nests depredated during one week was highest in wetland habitats: $52 \%$ was depredated in the marsh and $32 \%$ in the reed bed. However, a much lower damage rate (16\%) was experienced in the meadow. The daily survival rate of nests did not differ significantly between the reed bed (0.95) and the marsh (0.91). However, the daily survival rates of nests in the meadow (0.98) were significantly higher $(z=2.49 P=0.01)$ than in the marsh, bat no difference was found with comparing with the reed bed. Predators were difficult to determine because plasticine eggs usually disappeared from the nests in the reed bed. In the marsh and the meadow, primary predators were smaller birds, whereas small mammals were also important in the marsh. Nests in which predators succeeded in breaking at least one egg were later destroyed mostly by Hooded Crows Corvus cornix. To apply these results for bird protection, the breeding success of certain threatened bird species should be monitored for a longer period.

\section{INTRODUCTION}

Tn natural conditions, wetlands in the Mediterranean area are very 1 diverse and therefore sustain a high diversity of breeding birds (1). The Krka National Park, situated in the Šibenik-Knin county in Croatia, encompasses the most valuable area around the river Krka and the lower section of river Čikola. Based on surveys carried out between 1987-1989 and literature data, a total of 221 bird species were registered in Krka National Park (2). During the investigations performed between 2002-2004, 211 bird species were found to occur within the current boundaries of the National Park (3). The ornithofauna along the river Krka is characterised by low numbers of wetland species and higher representation of species associated with terrestrial habitats. This is re- 
flected also in the proportions of breeding species $(20 \%$ vs. $80 \%)(2,3)$. River Krka and surrounding plateau as habitat for 11 endangered bird species (among them endangered species like Great Bittern Botaurus stellaris, Little Crake Porzana parva, Spotted Crake Porzana por$z a n a$ are characteristic wetland species) is included in most important areas for the protection of threatened bird species in Croatia. The largest part of this area lies within the boundaries of Krka National Park (4). The study and identification of the environmental factors that influence population size is a key requirement for species conservation programs (5). Nest predation is one of the primary causes of breeding failure and affects populations and exerts strong selection on avian behaviour and life-history strategies (6). Therefore it is important issue both generally to ornithology and specifically to avian conservation (7). Experimental nest predation studies have greatly contributed to a better understanding of both breeding success and nest predation (8). Artificial nests have been useful in recording differences in predation rates as a function of habitat, nest and egg characteristics, nest location and density, and seasonal variations $(8,9)$. Differences in predation rate between habitats are also influenced by how birds and predators use those habitats (10).

The aim of our study was to investigate how nest predation influences the daily survival rates of eggs in nests of ground-nesting birds of wetland as well as terrestrial habitats in Krka National Park.

\section{METHODS}

Nest predation was studied in a particularly significant conservation area of Krka National Park (11). The locality Čulišićke bare wetland area (WJ75 according to $10 \times 10 \mathrm{~km}$ UTM grid) is situated between the Podbare bay of river Krka and the Dubravice settlement $(12,13)$. The proportion of breeding bird species associated with wetland and terrestrial habitats in this locality according to ornithological survey done from 1987 to 1989 was $31 \%$ vs. $69 \%$, respectively (2). The area gradually ascending from the riverside towards the settlement (49-65 m a.s.l.) is covered by reed beds, marshes and meadows. In each of these habitats 25 artificial ground nests were created at least $20 \mathrm{~m}$ apart (8). The height of vegetation cover around the nests was $148.6 \pm 31.14 \mathrm{~cm}$ (average $\pm \mathrm{sd}$ ) in the reed bed, 32.3 $\pm 7.84 \mathrm{~cm}$ in the marsh, and $38.1 \pm 7.27 \mathrm{~cm}$ in the meadow.

On 3 May 2004, three brown chicken eggs and a half sized plasticine egg were placed into each of the nests (14, 15). Both plasticine and chicken eggs were stored outdoors for one week before the start of the experiment. A $1 \mathrm{~cm}$ wide, $10 \mathrm{~cm}$ long pale orange tape was used for marking the place of each nest. This sign was always 5-20 m away from the nests, tied on a reed stem in the edge of the reed bed. In the marsh and in the meadow, tapes were attached to a $45 \mathrm{~cm}$ long, thin stick, $5 \mathrm{~m}$ from the nests, always in the same direction. The nests were checked on days 1 (4
May), 2 (5 May), 4 (7 May) and 7 (10 May), between $10 \mathrm{~h} 00$ and $12 \mathrm{~h} 00$ each day. Care was taken not to make any changes to the nests during checking.

The chicken (real) eggs were used for the evaluation of nest predation rates, and plasticine (artificial) eggs for predator identification from tooth and bill imprints. The survival rates of nests were calculated with the Mayfield method (16) and daily survival rates compared using the test proposed by Johnson (17). A minimum tail probability level of $\mathrm{P}<0.05$ (i.e. Type I error rate of 5\%) was accepted for all the test statistics, and all P-values were two-tailed.

\section{RESULTS}

During the one-week study period in the area between the Podbare bay of Krka river and the settlement Dubravice predators damaged $32 \%$ of nests contained chicken eggs in reed beds, $52 \%$ in marshes and $16 \%$ in meadow habitats. The daily survival rate of nests did not differ significantly $(\mathrm{z}=1.24 \mathrm{P}=0.21)$ between the reed bed 0.95 (= 94.77\%, 95\% confidence limits: $91.17-98.37)$ and the marsh 0.91 (91.10\%, c.l.: 86.36 - 95.81). However, the daily survival rates of nests in the meadow $0.98(97.65 \%$, c.l.: 95.32 - 99.97) were significantly higher $(\mathrm{z}=2.49 \mathrm{P}$ $=0.01)$ than in the marsh (0.91), bat no difference was found with comparing with the reed bed (0.95) (Fig. 1).

In the nests located in reed bed predators did not left marks on plasticine eggs, as they either remained intact or disappeared completely from the nests $(n=12)$. In the marsh three plasticine eggs disappeared, whereas five preserved beak markings and another three had tooth marks on them. In the meadow two plasticine eggs had marks left by small bodied birds.

\section{DISCUSSION}

Our results suggest that the survival chances of ground nests in wetland habitats (reed bed, marsh) are lower than

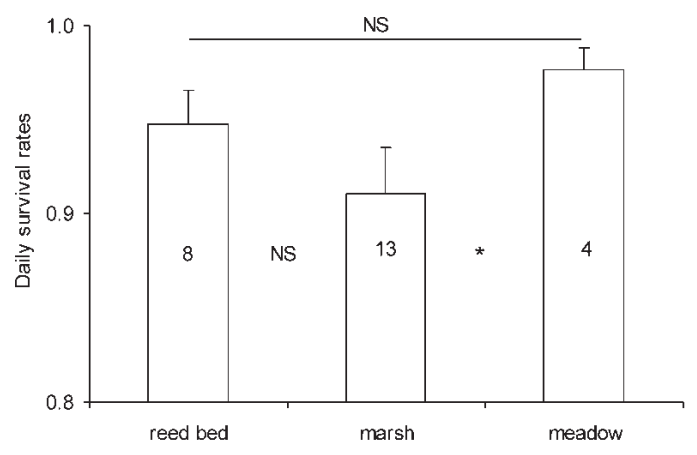

Figure 1. Comparison of daily survival rates (+SE) of chicken eggs in ground nests located in three different habitats near Krka river. The numbers in the bars indicate the numbers of nests with predated eggs (*: $P<0.05)$ 
in terrestrial habitats (meadow). The same results were shown also from the Mediterranean region, from the vicinity of Vrana lake (15), which is located $30 \mathrm{~km}$ northwest and also near Kuti lake (14), which is located $170 \mathrm{~km}$ southwest from the Krka National Park. On the both mentioned localities predator pressure was higher in reed bed than in open habitats (pastures or meadows). Howard et al. (18) suggested that vegetation structure did influence predation rates on artificial nests, daily mortality decreased significantly with increasing vegetation height. In our study, despite that the highest number of nests discovered by various predators occurred in the marsh with low vegetation, the height of plant cover did not seem to considerably influence nest predation. This is supported by the fact that in the reed bed with similarly high predation to nests, the height of vegetation is 4-5 times higher than what was measured in the marsh or in the meadow.

During our experiment, a large proportion of plasticine eggs were completely removed from the depredated nests in the reed bed, preventing us from identifying predators. Predators were large enough to be able to carry away plasticine eggs, but removing, breaking and eating the content of chicken eggs must have been impossible for them. Usually only one of the three chicken eggs was broken, with even the content being only partially consumed. We also found droppings of Red Fox Vulpes vulpes and Otter Lutra lutra nearby the nests, but if these predators had discovered the nests, most probably all eggs would have been instantly eaten. Predators of the nests in the marsh were usually small birds and small mammals. These predators succeeded in breaking at least one real egg in some nests, where eggs were later damaged by Hooded Crows Corvus cornix. We often observed potential egg predators above the studied area, e.g. Yellow-legged Gulls Larus cachinnans, once a Magpie Pica pica, Ravens Corvus corax and Jackdaws Corvus monedula too $(12,13)$. Olsen and Schmidt suggested that Hooded Crow activity increased markedly and instantly after the exposure of artificial nests, whereas Magpies showed no response to the nests, but seemed to be negatively influenced by Hooded Crows (19). Despite the fact that we used brown eggs, which have better survival chances than white ones (20), the light-coloured inside of already broken eggs, may have called the attention of larger birds. When checking the nests in marsh with the low-vegetation, we often could point out the white eggshell pieces even before actually reaching the nests. One could even ask whether the marking tapes might have also attracted visually searching predators to the nests. Tape pieces used for marking the nests were not placed directly beside the nests; therefore it is not likely that they could influence predator activity, as much less nests were discovered in the meadow. In this habitat predators were small birds. The lack of small mammal predatory activity may also have contributed to less chicken eggs being broken, meaning that secondary predators were not attracted to the nests either.

\section{CONCLUSION}

Our results indicated that predation pressure on ground nests in wetland habitats (reed bed, marsh) was higher than in terrestrial habitats (meadow). This can be an explanation to earlier observations that less bird species nest on ground in wetlands than in terrestrial habitats near river Krka. The applied methods were appropriate for the study without disturbance to endangered birds, and for comparing daily survival rates of nests in different habitats. Predators in the reed bed were difficult to determine because some plasticine eggs disappeared from the nests. In the marsh and the meadow, primary predators were smaller birds, whereas small mammals were also important in the marsh. These predators succeeded in breaking at least one real egg in some nests, where eggs were later damaged by Hooded Crows. The results of studies with artificial nests may be useful in the prediction of predation risk to real nests only when the predator species are the same for the two nest types. For applying these results in bird protection, we suggest more detailed research on predation rate at species level (i.e. threatened birds), and the identification of predators using trail cameras.

Acknowledgements: We would like to thank Drago Marguš (Krka NP) and the Šišak family (Dubravice) for supporting and assistance in field work. The study was supported by the grant „Predation as a threat for reintroduced birds - International Project Croatian Academy of Sciences and Arts", within an agreement of scientific cooperation (2003-2006). Investigations were permitted by the Ministry of Culture, Nature Protection Directorate (532-08/1-04-02).

\section{REFERENCES}

1. NAGER R G, HAFNER H, JOHNSON A R, CÉZILLY F 2010 Environmental impacts on wetland birds: long-term monitoring programmes in the Camargue, France. Ardea 98(3): 309-318. http://dx.doi.org/10.5253/078.098.0305

2. STIPČEVIĆ M, SUŠIĆ G, RADOVIĆ D, BARTOVSKY V 1990 Ornithofauna of the National Park Krka (in Croatian). Croatian Ecological Society, Ekološke Monografije 2: 505-522.

3. KRALJ J 2007 Ornithofana of the National Park Krka - changes and trends in 20-years period (in Croatian). In: Marguš D (ed) Book of Papers: Krka River and Krka National Park Symposium: Cultural and natural heritage, conservation and sustainable development, Šibenik, p 371-378

4. TUTIŠ V, KRALJ J, RADOVIĆ D, ĆIKOVIĆ D, BARIŠIĆ S (ed) 2013 Red Data Book of birds of Croatia. Ministry of Environmental and Nature Protection, State Institute for Nature Protection, Zagreb, p 258

5. HOFFMANN L, HAFNER H, SALATHÉ T I996 The contribution of colonial waterbird research to wetland conservation in the Mediterranean region. Colon Waterbird 19(Special Issue 1): 12-30. $10.2307 / 1521942$

6. SAÉTHER B -E 1996 Evolution of avian life histories - does nest predation explain it all? Trends Ecol Evol 11(8): 311-312. http://10.1016/0169-5347(96)30032-3 
7. ORTEGA CP, ORTEGA J C, RAPP CA, BACKENSTO S A 1998 Validating the use of artificial nests in predation experiments. J Wildlife Manage 62(3): 925-932. https://doi.org/10.2307/3802544

8. MAJOR R E, KENDAL CE 1996 The contribution of artificial nest experiments to understanding avian reproductive success: a review of methods and conclusions. Ibis 138(2): 298-307. http://10.1111/j.1474-919X.1996.tb04342.x

9. WILSON G R, BRITTINGHAM M C, GOODRICH L J 1998 How well do artificial nests estimate success of real nests? Condor 100(2): 357-364. https://doi.org/10.2307/1370277

10. BAYNE E M, HOBSON K A, FARGEY P 1997 Predation on artificial nests in relation to forest type: contrasting the use of quail and plasticine eggs. Ecography 20 (3): 233-239. http://10.1111/j.1600-0587.1997.tb00366.x

11. SUSIĆ G, STIPČEVIĆ M, RADOVIĆ D, BARTOVSKY V 1990 Ornithological assessment of the National Park Krka and proposals for measures of protection and management (in Croatian). Croatian Ecological Society, Ekološke Monografije 2: 587-599

12. MUŽINIĆ J, PURGER J J 2007 Problems of the preservation of bird diversity in locality Čulišićke bare (Krka National Park, Croatia (in Croatian). In: Marguš D (ed) Book of Papers: Krka River and Krka National Park Symposium: Cultural and natural heritage, conservation and sustainable development, Sibenik, p 379-386
13. PURGER J J, MUŽINIĆ J 2007 New data on the ornithofauna of Čulišićke bare wetland area in Krka National Park (Croatia). Acrocephalus 28(135): 170-171

14. PURGER J J, MUŽINIĆ J 2010 Possible effects of nest predation on ground nest survival in the Neretva delta (Croatia). Avian Biol Res 3(2): 81-83. http://10.3184/175815510X12742877305353

15. PURGER J J, MUŽINIĆ J, PURGER D 2012 Survival chances of ground nests in a meadow habitat: a case study in Vrana lake Nature park (Mediterranean region, Croatia). Pol J Ecol 60(1): 207-212

16. MAYFIELD H F 1975 Suggestions for calculating nest success. Wilson Bull 87(4): 456-466

17. JOHNSON D H 1979 Estimating nest success: the Mayfield method and an alternative. Auk 96(4): 651-661

18. HOWARD M N, SKAGEN S K, KENNEDY P L 2001 Does habitat fragmentation influence nest predation in the shortgrass prairie? Condor 103(3): 530-536.

https://doi.org/10.1650/0010-5422(2001)103[0530:DHFINP]2.0.CO;2

19. OLSEN H, SCHMIDT N M 2004 Response of Hooded Crow Corvus corone cornix and Magpie Pica pica to exposure to artificial nests. BirdStudy 51(1): 87-90. https://10.1080/00063650409461337

20. YAHNER R H, MAHAN C G 1996 Effects of egg type on depredation of artificial ground nests. Wilson Bull 108(1): 129-136 